\title{
Independent Smallholder Oil Palm Expansion and Its Impact on Deforestation: Case Study in Kampar District, Riau Province, Indonesia
}

\author{
Erniwati ${ }^{\text {**, Ervizal AM. Zuhud², Iswandi Anas }}{ }^{3}$, Arzyana Sunkar ${ }^{2}$, Yanto Santosa ${ }^{2}$ \\ 'Department of Forestry, Faculty of Agriculture, Universitas Bengkulu. Jl. W.R. Supratman, Kota Bengkulu, \\ Bengkulu, Indonesia 38371 \\ ${ }^{2}$ Department of Forest Resource Conservation and Ecotourism, Faculty of Forestry, Ulin Road, \\ Bogor, Indonesia 16680 \\ ${ }^{3}$ Department of Soil Science and Land Resources, Faculty of Agriculture, IPB. Dramaga Main Road, \\ Bogor, Indonesia 16680
}

Received July 19, 2017/Accepted November 20, 2017

\begin{abstract}
Independent oil palm plantation smallholders are those who managed their plantations free of technical assistances and agricultural inputs from oil palm estates or government. Although their numbers have been increasing rapidly in Indonesia in recent years, however, the magnitude of their impacts on tropical forest deforestation remained largely unevaluated. The objectives of this study were to explore the history of land use, land cover changes and land status since the start of oil palm plantation activities. The study was conducted from March to April 2016 and carried out in 30 ha of independent oil palm smallholders in Kampar District of Riau Province. To identify the land status, Forest Land Use by Consensus (TGHK) and Provincial Land Use Planning (RTRWP) maps were overlaid using satellite images of the independent oil palm smallholding areas. Landsat imageries of three years prior to the oil palm establishment were used to assess the forest cover changes. In addition, from the local perspectives, interviews were conducted with the smallholders and the elders of the local communities, to identify the prior land uses. Based on land status, the results showed that $47 \%$ of the independent smallholders' areas were derived from logged over forest, while the other 53\% were derived from non-forested land. The land uses before the establishment of the smallholdings were mostly comprised of general-purpose field activities and forest concessions. The land cover prior to the conversion to oil palm plantations comprised of rubber plantations, secondary forest, and shrubs. Results of this research indicated that most of the areas where oil palm plantations were established and planted between 1990 and 2002, were originated from degraded secondary forest, dryfields, and shrub-land, and were not converted from primary forests. These findings implied that deforestation did not occur in the tropical forests of Kampar, Riau Province.
\end{abstract}

Keywords: land history, land status, land cover change, deforestation, tropical forest

*Correspondence author, email: erniwati@unib.ac.id, ph.: +62-73621170

\section{Introduction}

Tropical forest in Indonesia contains high floral and faunal biodiversity, including $10 \%$ of the world's plants, $12 \%$ of the world's mammals, $16 \%$ of the world's reptile-amphibians, $17 \%$ of the world's bird species, and 15 $\%$ of the world's insects (Primack 2012). Unfortunately, Indonesia's tropical forest has undergone deforestation and forest degradation. In the periods of 1990 to 2012, the annual rate of deforestation in Indonesia was 918,678 ha year ${ }^{-1}$, with the highest rate of deforestation occurred during the period of 1996-2000, which accounted for more than 2.2 million hayear $^{-1}$ (MoEF 2015). Indonesia has lost more than 6 million ha of its tropical forest between 2000 and 2012, due to forest clearance mainly for the purposes of agriculture and of industrial timber plantations expansions (Margono et al.
2014). Although in 2011-2012, the rate of deforestation has declined to about 786,000 ha years ${ }^{-1}$ (MoEF 2015), the current rate is still of concern because Indonesia is recognised as one of the world's mega diverse countries.

Over the last three decades, oil palm plantations have increased rapidly in Indonesia due to the increasing global demands for oil palm's products. Palm oil is the most broadly utilized vegetable oil in the world since it is more productive than other crops such as soybean, sunflower and rapeseed. Furthermore, oil palm can also grow on degraded or marginal lands.

Indonesia is the largest producer of palm oil, contributing approximately $50 \%$ of the global palm oil. Between 1995 and 2016, the area under oil palm plantation increased sharply from 1.1 million ha to 11.67 million ha. Sumatera 
accounts for approximately $67 \%$ of Indonesia's total planted oil palm area and about $74 \%$ of the national crude palm oil production. Riau, a province of Sumatera, is the largest palm oil producing province in Indonesia, with a total area of 2.5 million ha of oil palm plantations (Ministry of Agriculture 2015).

The conversion of forest areas into oil palm plantations is often referred to as one of the main drivers of deforestation in Indonesia (Fitzherbert et al. 2008; Koh 2009). However, previous studies showed that from 1997 to 2003, about 2.6 million ha of land were converted to oil palm plantations, while in the same period, 9.7 million ha of forest cover was lost. This suggests that oil palm may have been responsible for only at most $27 \%$ of all deforestation (Wicke et al. 2011), although the real percentage is likely to be lower considering other land types such as degraded land and other plantations, were also converted to oil palm plantations (Pagiola 2000; Gunarso et al. 2013). According to Fitzherbert et al. (2008), assuming that the entire plantation areas were converted from forests, about $16 \%$ of deforestation were caused by oil palm establishment. Therefore, it is difficult to determine the exact percentage of forest conversion until more specific data are known, especially on the history of land used for palm oil production (Wicke et al.2011).

Development of Indonesia oil palm plantations, has been driven by both large-scale plantations and smallholdings. Large-scale plantations are either state-owned or private estates with a total area up to 10,000 ha, while smallholding oil palm plantations are on average $2-5$ ha in size, but can range up to 50 ha. Oil palm smallholdings can be managed independently without receiving any technical assistances from large-scale oil palm (independent smallholder) or they can be managed in association with an oil palm company (contract smallholder schemes) where farmers get specialized assistance and received agricultural inputs for their plantation with the advantage of a shared contract.

As documented in the 2014-2016 Palm Oil Statistics of Indonesia, Indonesia's oil palm smallholdings have increased from $2,549,428$ ha to $4,763,797$ ha (an increase of $87 \%$ ) in the most recent decade, surpassing the state-owned plantations $(687,428-755,787 \mathrm{ha}$; an increase of $10 \%)$ and the private enterprise estates $(3,357,914-6,153,277 \mathrm{ha}$; an increase of $83 \%$ ). Smallholder plantation development concentrated in Riau, increasing from 740,348 ha in 2006 to $1,441,705$ ha in 2016 (an increase of 95\%). By comparison, private enterprise estates increased by $30 \%$ from 715,552 ha in 2006 to 931,662 ha in 2016 and state-owned plantations increased by $29 \%$ from 68,861 to ha $-88,728$ ha. The sharp development of smallholder oil palm in Indonesia indicates an important contribution to future land cover changes, through small to medium size land conversions.

The degree to which oil palm has contributed to deforestation is still debatable due to the various definitions used for the term 'deforestation'. In Indonesia, deforestation is mostly used in a practical sense. Regulation of Minister of Forestry Number 30/2009 states that deforestation is the permanent alteration of a forested area into a non-forested area as a result of human activities. The practical definition emphasises land cover rather than land use, and consequently, differs from the definition used by the FAO (2010), which defines it as the conversion of forest to other land uses or the long-term reduction of the tree canopy cover below the minimum $10 \%$ threshold (FAO 2010).

Forest area and forest cover, are two terms that are commonly discussed in relation to deforestation in Indonesia. Forest area refers to land appointed by the Indonesian government to be sustained as a permanent forest and functions to serve as an economic generator at the local, regional and national levels in Indonesia. Forest area includes conservation forest (designated for wildlife or habitat protection), protection forest (intended to serve environmental functions such as maintaining vegetation cover or protecting watersheds), and production forest (for both permanent and limited production of timber). Often, conversion forest also includes forest that is intended to be converted to other uses.

In contrast, the term forest cover refers to the actual vegetation cover of an area. Acknowledging the difference between forest area and forest cover, is important to better understand the changes that have occurred for Indonesian forests. Gunarso et al. (2013) state that differences in the use of the term 'deforestation' have led to various interpretations of data and hence have led to misunderstandings concerning the impacts of oil palm plantations on deforestation

Numerous studies have documented the relationship between oil palm expansion and environmental impacts (Koh \& Wilcove 2008; Uryu et al. 2008; Koh et al. 2011; Carlson et al. 2012; 2013; Miettinen et al. 2012; Obidzinski et al. 2012; Gunarso et al. 2013; Lee et al. 2013; Tarigan et al. 2015), but little is known on the impacts of independent oil palm smallholdings in Indonesia. Moreover, previous studies have not described in details, the various driving factors behind deforestation (Wicke et al.2011), such as land status, land use history, and land cover types of the areas before they were converted to oil palm plantations (Koh et al. 2011). Lack of data on land cover changes and incomplete understanding of the complex factors involved, have led to difficulties in quantifying the extent of oil palm as the direct cause of deforestation. This is particularly true for independent oil palm smallholders who are growing rapidly in number and are likely to dominate the Indonesian future oil palm plantation industry (Euler et al.2016). This article studied the impacts of Indonesia's independent oil palm smallholdings on deforestation in Riau Province as the biggest oil palm producing province in Indonesia. Specifically, these were achieved by performing a land cover change analysis and by conducting interviews with smallholders regarding history of the land.

The objective of this study was to determine the history of the land status, land use and land cover changes, prior to the establishment of independent smallholder oil palm plantations in Kampar District of Riau Province. The results of this study would provide knowledge on the relationships between expansions of oil palm smallholdings with the deforestation phenomenon.

\section{Methods}

The research was conducted in the Province of Riau (8.9 million ha). The province is located at $2-91 \mathrm{~m}$ a.s.l., between latitudes $\mathrm{S} 01^{\circ} 05^{\prime} 00^{\prime \prime}$ and $\mathrm{N} 02^{\circ} 25^{\prime} 00^{\prime \prime}$, and between longitudes $\mathrm{E} 100^{\circ} 00^{\prime} 00^{\prime \prime}$ and $\mathrm{E} 105^{\circ} 05^{\prime} 00^{\prime \prime}$. The province has an average rainfall ranging from 1,000-3,000 $\mathrm{mm}$ year-1, 
with a dry season (April-September) and a rainy season (October-March). The Province of Riau comprises of 12 districts, namely Kampar (the largest district), Pelalawan, Siak, Kuantan Singigi, Indragiri Hulu, Indragiri Hilir, Bengkalis, Dumai, Kepulauan Meranti, Rokan Hulu, Rokan Hilir, and Pekanbaru as the capital of the province. The research was conducted in the District of Kampar from March to April 2016. The focused was largely on independent oil palm smallholdings. The total land area of the oil palm observed was 30 ha, covering eight different smallholdings with the year of establishment ranged from 1990-2009.

The Forest Land Use by Consensus (TGHK) maps were obtained from the Ministry of Forestry, while GIS datasets of Riau Provincial Spatial Plan (RTRWP) were obtained from the Riau Provincial Government, and GIS datasets of Riau forest area were obtained from the Riau Provincial Forestry Office. To analyse the status and origin of the oil palm plantations, GIS datasets were overlaid with GIS data of independent oil palm smallholding areas taken from field observations.

To assess the historical land-cover changes, i.e. the changes in land covers from the time before the establishment of independent oil palm smallholdings to the time of study, Landsat Imageries were used. Landsat images of land covers were acquired for three years before the smallholder oil palms were planted. The classification of land cover followed the definitions given by the Directorate General of Planning, Ministry of Forestry, i.e.: primary forest, secondary forest, plantation, mixed field (agroforestry), dry field, open area, water body, and shrubland. All the analyses were done using ArcGIS software. In addition, interviews were conducted with the farmers and the elders, to identify the land uses prior to the plantations and legal documentations on their land. Furthermore, interviews were also conducted with government officials related to land tenure in the area. Literature reviews were also conducted concerning the history of the land.

\section{Results and Discussion}

Land, according to the Indonesian ForestryAct No. $41 / 1999$ is categorized into forest and non-forest areas (other land uses), while other land uses are designated for nonforestry development. Other land uses were under the authority of local government, both at provincial and district/city levels. On the other hand, forest areas are under the authority of the central government. Forest Land Use by Consensus (TGHK/Tata Guna Hutan Kesepakatan) is the functional classification for Indonesia's forestlands, which comprised of protection forest, conservation forest, production forest, and conversion forest (production forest that could be converted to other uses). The TGHK was established in 1983 by the Department of Forestry and agreed by all provincial governments and other sectors. The Provincial Spatial Plan (RTRWP/Rencana Tata Ruang Wilayah Provinsi) is the spatial management plan of the provincial land area as an elaboration of the Spatial Management Act of 1992. The spatial classifications according to the RTRWP are protection forest, forest land cultivation area, and non-forest cultivation area. Since 1993, the two functional land classification systems, have been integrated in their implementations.

Riau Spatial Regulation referred to the Decree of the Minister of Forestry Number 173 of 1986 on TGHK and Local Regulation Number 10 of 1994 on the 1992-2009 RTRWP, which stated that spatial utilization was used as a reference and coordination tool among sectors, in developing policies for Riau Province. In accordance with TGHK, the land area of Riau was 8,598,757 ha, and has been updated to $9,036,835.00$ ha in 2012. Nevertheless, only $42.55 \%$ (3,032,912 ha) of forest lands in Riau Province were covered with forest, while the remaining $57.45 \%$ were without forest coves $(4,094,326$ ha).

Results of the study showed that based on TGHK, as much as $47 \%$ of the independent smallholdings areas, had the status of 'production forest', while $53 \%$ of the area had the status of 'non-forest land (other land uses)'. Furthermore, based on the map on Riau forest area (2014), 66\% of the independent smallholder oil palm areas were not 'forest land', and $33 \%$ of the area had the status of ' converted forest ' (Table 1). Based on the RTRWP, 47\% independent smallholdings had the status of 'forest land ', 27\% had the status of 'non-forest cultivation area' while the remaining $36 \%$ had the status of 'non-forested area (other land uses)'. Moreover, based on the 2014 updated RTRWP, all areas of the independent smallholdings had the status of 'nonforested area (other land use)'. Based on both the TGHK and Riau RTRWP, there was an indication that almost half of the independent smallholdings were located on forest land. However, based on the 2014 updated Riau's RTRWP, all of the independent smallholdings areas, were declared to be previously 'non-forested land'. According to the Indonesia regulations, a 'production forest' can be converted into 'conversion forest' or 'other land uses' if the forest area was determined to be unproductive (Kartodihardjo \& Supriono 2000).

The independent oil palm smallholders with plantations located in forest areas, had legal documentation of land ownerships, although legally, this would not be permitted since forest land is under the ownership and management of the central government (Ministry of of Environment and Forestry) (Table 1). This study indicated that there was an overlapped of land status between TGHK and RTRWP. Such overlapping status might have occurred due to the misalignment between the land use in RTRWP and the TGHK for Riau Province. According to Sinabutar (2015), in arranging forest and other lands, the local government followed the RTRWP, while the Ministry of Environment and Forestry followed the TGHK. Different sources of regulation could trigger uncontrolled land use, which could lead to unclear forest boundaries, e.g. forest land controlled by the state can in such cases, be owned by oil palm smallholders since they have the official proofs of the land ownership, i.e. a letter of proof from the head of village (SKT) or a certificate issued by the National Land Agency (BPN). Should this circumstance persist, it would threaten the sustainability of forests because demands for oil palms will continue to rise into the near future (Corley 2009).

Land ownership by local communities were generally based on the concept of first-come-first-serve, meaning that whoever first farmed the area, he/she has the right of possession over the land (Saptomo 2004). The planting of 
Table 1 The previous use and status of land prior to the establishment of independent smallholder oil palm in Kampar District, Riau Province

\begin{tabular}{|c|c|c|c|c|c|c|c|}
\hline \multirow[t]{2}{*}{ Location } & \multirow[t]{2}{*}{ Width (ha) } & \multirow[t]{2}{*}{$\begin{array}{c}\text { Year of } \\
\text { planting }\end{array}$} & $\begin{array}{l}\text { TGHK } \\
\text { (1986) }\end{array}$ & $\begin{array}{c}\text { RTRWP } \\
\text { Riau (1994) }\end{array}$ & $\begin{array}{c}\text { RTRWP } \\
\text { Riau (2014) }\end{array}$ & $\begin{array}{c}\text { Forest area } \\
\text { of Riau } \\
(2014)\end{array}$ & \multirow[t]{2}{*}{$\begin{array}{c}\text { Proof of } \\
\text { document }\end{array}$} \\
\hline & & & Status & Status & Status & Status & \\
\hline Plantation 1 & 4 & 1990 & $\begin{array}{l}\text { Forest } \\
\text { production }\end{array}$ & $\begin{array}{l}\text { Forest land } \\
\text { Cultivation } \\
\text { area }\end{array}$ & Other land & Other land & SKT \\
\hline Plantation 2 & 10 & 1998 & $\begin{array}{l}\text { Forest } \\
\text { production }\end{array}$ & $\begin{array}{c}\text { Forest land } \\
\text { Cultivation } \\
\text { area }\end{array}$ & Other land & $\begin{array}{l}\text { Conversion } \\
\text { forest }\end{array}$ & Certificate \\
\hline Plantation 3 & 1 & 2009 & Other land & Other land & Other land & Other land & SKT \\
\hline Plantation 4 & 1 & 2009 & Other land & Other land & Other land & Other land & SKT \\
\hline Plantation 5 & 4 & 1998 & Other land & $\begin{array}{l}\text { Non-forest } \\
\text { land } \\
\text { Cultivation } \\
\text { area }\end{array}$ & Other land & Other land & Certificate \\
\hline Plantation 6 & 4 & 1998 & Other land & $\begin{array}{l}\text { Non-forest } \\
\text { land } \\
\text { Cultivation } \\
\text { area }\end{array}$ & Other land & Other land & Certificate \\
\hline Plantation 7 & 4 & 2000 & Other land & Other land & Other land & Other land & Certificate \\
\hline Plantation 8 & 2 & 2002 & Other land & Other land & Other land & Other land & Certificate \\
\hline
\end{tabular}

TGHK: Forest Land Use Agreement, RTRWP: Riau Province Spatial Plan

sites within forest areaswith agricultural crops such as rubber or mix-fields, and then converting it into oil palm is seen as a proof of ownership over the land, especially in areas where there are many land competitions (Sunderlin et al. 1997). Planting rubber trees may be the community strategy in Riau to obtain and secure land rights according to customary and state laws (Angelsen 1995). This strategy was also documented in West Kalimantan where the communities use it to fight land encroachment by other tribes or by government (Dove 1993). Overlapping definitions of land status triggered uncertainty in the legitimacy of land ownership and land use (Kartodihardjo 2011; Fauzi 2013; Nugraha 2013). Overlapping claims over forest areas can be caused by several factors including: inefficient policy implementation, uncoordinated permits, and lack of recognition of the rights of indigenous peoples and local communities (Sinabutar 2015).

With regard to the history of land use and change, analysis of satellite imageries showed that three years before the lands were converted into oil palm plantations, as much as $27 \%$ of the area weres covered by secondary forest, $27 \%$ by shrub, and $33 \%$ by plantation, while the other $13 \%$ were undetermined, due to lack of available data. Two years before the independent smallholdings were established, $33 \%$ of the areas were covered by secondary forest, while $60 \%$ of the area were covered by shrub, and $7 \%$ were open areas. Finally, analysis of imageries taken just one year before the planting of oil palm, showed that secondary forest cover had fallen from $33 \%-10 \%$, shrub had increased to $63 \%$ and open area was reduced to $3 \%$, while $3 \%$ were replaced by oil palm plantations. These land cover changes in the study area were clearly seen in the Landsat images of one of the independent smallholder oil palm area shown in Figure 1.

In the interviews with the farmers, $80 \%$ stated that their lands were originally derived from land covered with forest, and $20 \%$ said from land covered with shrubs (Table 2 ). These results were slightly different from the results obtained from the Landsat Imageries. These discrepancies arose from differences between the farmers' perceptions and definitions of forest covers and the definition of forest cover used in our analysis of the images. However, in general, these $t$ results implied that secondary forests and shrubs, covered most of the lands prior to the development of oil palm smallholder plantations. The difference of perceptions between what constitutes a primary forest and degraded forest is one of the factors that have led to unclear understanding of the impacts on forest brought about by oil palm plantations in Indonesia (Gunarso et al. 2013). The use of term 'intact primary forests' (Carlson et al. 2012; 2013) or 'primary forest degradation' (Margono et al. 2014) seemed to imply that the land planted with oil palm is usually originated from primary forests. The use of such terminology is based on several studies showing that degraded forests have high biodiversity (Hamer et al. 2003; Peh et al. 2005; 2006; Edwards et al. 2010).

Literature reviews of the land-use history prior to the establishment of the independent smallholdings showed that $46 \%$ of the land was formerly forest concessions, while $54 \%$ was formerly transmigration fields or mix fields used by the local community. These results were in line with the analysis of Landsat imageries showing that most of the land covers before convertion to oil palm plantations, were in the form of shrubs, secondary forest and open areas (Table 1). The results of this study is consistent with previous research findings that oil palm plantations in Indonesia are mostly planted on 


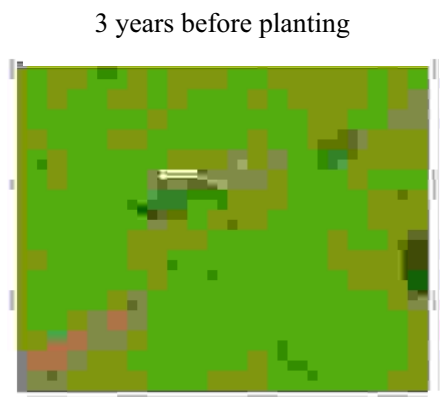

3 years after planting

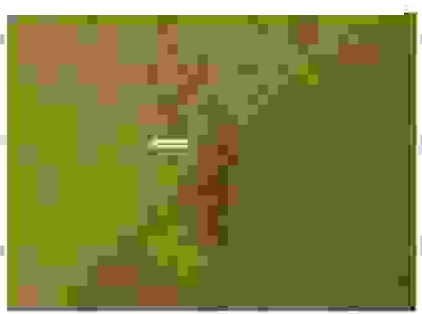

2 years before planting

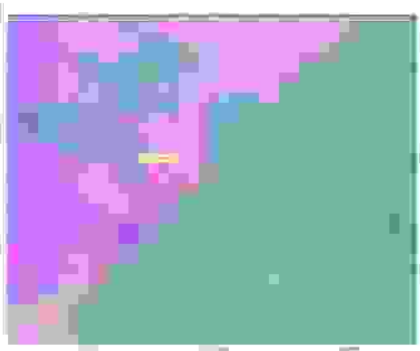

2 years after planting

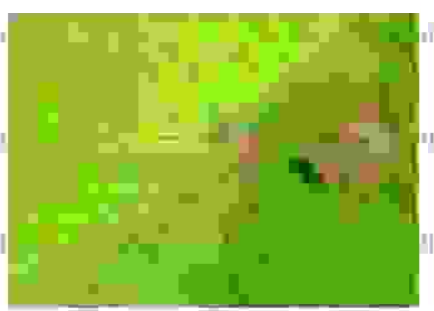

1 year before planting

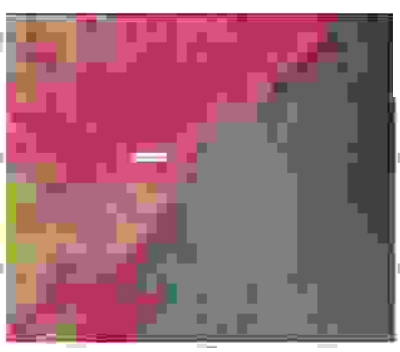

1 year after planting

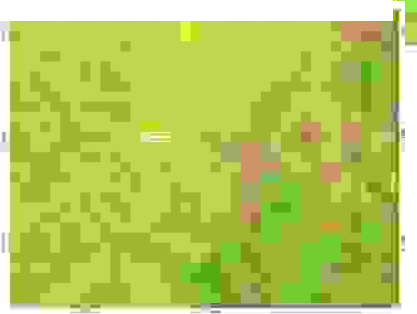

Year of oil palm planted before planting

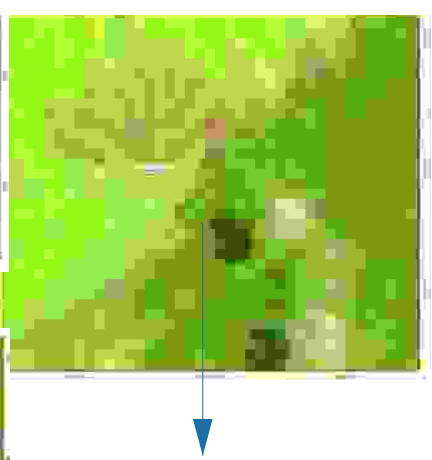

Smallholder oil palm

Figure 1 Landsat images of one of the independent smallholder oil palm holdings in the study area in Riau Province.

Table 2 Land cover changes prior to establishment of oil palm plantations based on Landsat imagery and on farmer interviews

\begin{tabular}{|c|c|c|c|c|c|c|c|}
\hline \multirow[b]{2}{*}{ Location } & \multirow[b]{2}{*}{ Width } & \multirow{2}{*}{$\begin{array}{l}\text { Year of } \\
\text { planting }\end{array}$} & \multicolumn{3}{|c|}{$\begin{array}{l}\text { Land cover change based on landsat } \\
\text { imagery (three years coverage) }\end{array}$} & \multirow{2}{*}{$\begin{array}{l}\text { Land cover } \\
\text { prior to } \\
\text { oil palm } \\
\text { according to } \\
\text { land owner }\end{array}$} & \multirow{2}{*}{$\begin{array}{l}\text { History of } \\
\text { landuse }\end{array}$} \\
\hline & & & $\begin{array}{l}3 \text { years } \\
\text { before } \\
\text { planting }\end{array}$ & $\begin{array}{l}2 \text { years } \\
\text { before } \\
\text { planting }\end{array}$ & $\begin{array}{l}1 \text { year before } \\
\text { planting }\end{array}$ & & \\
\hline Smallholder 1 & 4 & 1990 & $\begin{array}{l}\text { No data } \\
\text { available }\end{array}$ & $\begin{array}{l}\text { Secondary } \\
\text { forest }\end{array}$ & $\begin{array}{l}\text { Secondary } \\
\text { forest }\end{array}$ & Forest & $\begin{array}{l}\text { Former forest } \\
\text { concesion }\end{array}$ \\
\hline Smallholder 2 & 10 & 1998 & Plantation & Shrub & Shrub & Forest & $\begin{array}{l}\text { Former forest } \\
\text { concesion }\end{array}$ \\
\hline Smallholder 3 & 1 & 2009 & $\begin{array}{l}\text { Secondary } \\
\text { forest }\end{array}$ & Open area & Open area & Forest & $\begin{array}{l}\text { Former forest } \\
\text { field }\end{array}$ \\
\hline Smallholder 4 & 1 & 2009 & $\begin{array}{l}\text { Secondary } \\
\text { forest }\end{array}$ & Open area & Plantation & Forest & $\begin{array}{l}\text { Former forest } \\
\text { field }\end{array}$ \\
\hline Smallholder 5 & 4 & 1998 & Shrub & Shrub & Shrub & Forest & $\begin{array}{l}\text { Former forest } \\
\text { field }\end{array}$ \\
\hline Smallholder 6 & 4 & 1998 & Shrub & Shrub & Shrub & Forest & $\begin{array}{l}\text { Former forest } \\
\text { field }\end{array}$ \\
\hline Smallholder 7 & 4 & 2000 & $\begin{array}{l}\text { Secondary } \\
\text { forest }\end{array}$ & $\begin{array}{l}\text { Secondary } \\
\text { forest }\end{array}$ & $\begin{array}{l}\text { Secondary } \\
\text { forest }\end{array}$ & Shrub & $\begin{array}{l}\text { Former forest } \\
\text { field }\end{array}$ \\
\hline Smallholder 8 & 2 & 2002 & $\begin{array}{l}\text { Secondary } \\
\text { forest }\end{array}$ & $\begin{array}{l}\text { Secondary } \\
\text { forest }\end{array}$ & $\begin{array}{l}\text { Secondary } \\
\text { forest }\end{array}$ & Shrub & $\begin{array}{l}\text { Former forest } \\
\quad \text { field }\end{array}$ \\
\hline
\end{tabular}

lands converted from former fields and rubber plantations (Gunarso et al. 2013). Tarigan et al. (2015) concluded that most of the oil palm plantations in Jambi Province in the last 25 years, originated from former mix fields, logged-over forest and shrub lands; only $8 \%$ of oil palm plantations in that study, were found to be derived directly from forest clearance activity. Similarly, in Kalimantan, studies have reported that the lands used for oil palm plantations, were largely came from areas that were previously covered by shrubs (Carlson et al. 2012; Gunarso et al. 2013; Muin 2013).

Overall, the results of various studies showed that most of the oil palm areas planted in the years 1990, 1998, 2000, 
2002, and 2009 were originated from secondary forest, degraded forest, local mixed fields and former transmigration lands. The period of oil palm establishment is closely related to the origins and changes of land cover. In the early $1990 \mathrm{~s}$, the majority of oil palm plantations originated from forest land. Forest exploitations through forest concessions activities in the 1980-1990 era had transformed these lands into degraded forest. The degraded forests were then replaced with agricultural crops such as rubber, and later on were converted into oil palm plantations. This fact showed that the transformation of forest land into oil palm plantations was not a direct process. Between 1990 and 2005 , at least $50 \%$ of the expansion of oil palm plantation, were derived from forest lands in both Malaysia and Indonesia (Wilcove and Koh 2010). Results of this study are consistent with the previous research findings by Ramdani and Hino (2013) who conclude that the majority of tropical forest losses in Riau were related to the transmigration program, land clearance for rubber plantations and to large-scale oil palm and forest fires.

Forest clearing activities by smallholders in Indonesia, was better acknoeledged in the period up to the 1990s, during which time, the transmigration programs and smallholder tree crop development projects in the era of President Soeharto had facilitated accesses to forests by both local and migrant smallholders (Holmes 2002). After the 1990s, private agricultural enterprises were responsible for most of the tropical deforestation, due to increased demands for agricultural commodities on the global market (Margono et al. 2014). Following this, in the period of the 2000s, independent oil palm smallholdings began to dominate; mostly on land converted from former mixed fields and rubber plantations. As shown in our study (Table 2), oil palm smallholder plantations had mostly expanded from other forms of agriculture such as plantations and from shrub-land, which have been demonstrated to be less profitable to farmers in the short-term compared to oil palm productions (Belcher et al. 2004; Feintrenie et al. 2010). The period of 2000 s has been referred to as the second phase of oil palm development, during which about $85 \%$ of the land for oil palm plantations in Sumatera were converted from agricultural land uses such as rubber plantations and mixed fields (Gunarso et al. 2013). Between 2001 and 2005, the conversion of agroforestry and old plantation to oil palm was important, especially in Sumatera, a region where oil palm expansion increased sharply and was characterized by greater levels of human disturbance and land use change (Gunarso et al. 2013).

The various drivers of land cover change in Indonesia were closely related. Some of the plantation establishment was preceded by timber exploitation. Sometimes the two have been closely linked, since logging operations has sometimes been carried out as a direct part of the landclearing process. However, in other cases, establishing a causal linkage between the two is problematic, especially if timber exploitation and plantation establishment were separated by a time space of several years or longer. Past research have demonstrated that forested areas were favoured by oil palm private companies because timber incomes from these areas have helped to defray the expenses of setting up large-scale oil palm plantations (Casson 1999).

In fact, as indicated by our results, loss of secondary forest cover accounted for $27 \%$ of the total land cover losses within independent oil palm smallholdings. For the period between 2000 and 2010, Margono et al. (2014) distinguished oil palm and industrial timber plantations expansions as the primary driving forces, while transmigration activities and fires as secondary driving forces, associated with the loss of forest cover in Sumatera. This study showed that during this same time frame, in the study area, about $27 \%$ of the loss in secondary forest cover occurred within the independent smallholder oil palm plantation boundaries.

Previous studies that have looked into the environmental impacts of large-scale oil palm private companies and smallholdings have revealed that the smallholder oil palm sector in Sumatera between 2000 and 2010, have expanded faster than the large-scale. However, the environmental impacts resulting from the smallholder oil palm sector have been shown to be lower compared to the impacts of private enterprise sector, in terms of total forest losses in Sumatera; oil palm smallholdings accounted for eight times lower deforestation than large scale private estates, while stateowned plantations accounted for least deforestation (Margono et al. 2014). In another study, Uryu et al. (2008) also reported higher deforestation from oil palm private enterprises than oil palm smallholdings during 1982 to 2007.

The smallholders in the study areas, came from various socio-economic backgrounds. It is important to distinguish these from the environmental impacts of that activity. Jelsma and Schoneveld (2016) have classified the various smallholders in Riau into a typology. Wealthy farmers have cleared and transformed land into oil palm plantation more often than the average farmers due to the high capital required for such land clearing. In Riau, higher growth has been reported within the smallholder oil palm sector. Managing and monitoring the impacts of thousands of oil palm smallholders on forest, are very heavy tasks. Less efforts in such monitoring could threaten forest area in the future, especially within a forest landscape like Riau, which is becoming increasingly fragmented and exposed to smallholder agricultural conversion.

There study has attempted to quantify the deforestation impacts resulting from independent oil palm smallholdings in Kampar. Although the results have indicated that independent oil palm smallholdings were mostly established on degraded secondary forest, ex dry fields and shrub-land, the estimates required further investigation on a larger sample encompassing the twelve districts of Riau, because the annual expansion rate of the oil palm smallholder is higher than that of the large scale oil palm plantation (Directorate General of Plantations 2015). While oil palm plantation has been expanding rapidly in the recent decades, it is expected that oil palm smallholder would expand even further in the future (Euler et al. 2016). In order to manage the environmental impacts of independent oil palm smallholder plantation in Indonesia, it is suggested that it would be essential to monitor and to engage with these independent oil palm smallholders.

This study has attempted to quantify the deforestation impacts resulting from independent oil palm smallholdings 
in Kampar. Although the results have indicated that independent oil palm smallholdings were mostly established on degraded secondary forest, ex dry fields and shrub-land, the estimates required further investigation on a larger sample encompassing the twelve districts of Riau, because the annual expansion rate of the oil palm smallholder is higher than that of the large scale oil palm plantation (Directorate General of Plantations 2015). While oil palm plantation has been expanding rapidly in the recent decades, it is expected that oil palm smallholder would expand even further in the future (Euler et al. 2016). In order to manage the environmental impacts of independent oil palm smallholder plantation in Indonesia, it is suggested that it would be essential to monitor and to engage with these independent oil palm smallholders.

\section{Conclusion}

In general, most of the oil palm plantations planted between the years 1990 to 2002, were not converted from primary forest land, but originated from degraded secondary forest, dry fields and shrub-land. Based on land status, $47 \%$ of the independent oil palm smallholdings were previously logged-over forest that were subsequently classified with the status of converted forest, while the other $53 \%$ was on nonforested land. The land use prior to the conversion to independent oil palm smallholdings were mostly dryfields and ex forest concession areas. The land cover types of the areas before being converted into oil palm plantations were: plantation, secondary forest, and shrub-land. It can be concluded from the findings of this study that conversion of forest area into independent smallholder oil palm plantations was not a direct process. Deforestation that previously has occurred in the study area, might initially have been for the reasons that were not related to the subsequent planting of the land to oil palm. Therefore, in such case, the establishment of independent oil palm smallholder plantations, could not be held responsible as the main factor causing deforestation of tropical forests in the District of Kampar, Riau Province.

\section{Acknowledgements}

Our sincere thank you is forwarded to all farmers who gave us the permissions to conduct the field work on their land. This research was carried out as a part of the first author's $\mathrm{PhD}$ study, for which she received a scholarship from the Indonesian Endowment Fund for Education (Lembaga Pengelola Lembaga Dana Pendidikan; LPDP). The research was also supported by the Indonesian Oil Palm Estate Fund Agency (Badan Pengelola Dana Perkebunan Kelapa Sawit(BPDPKS).

\section{References}

Angelsen A. 1995. Shifting cultivation and deforestation: a study from Indonesia. World Development 23(10):1713-1729. https://doi.org/10.1016/0305$750 \mathrm{X}(95) 00070-\mathrm{S}$.

Belcher B, Rujehan, Imang N, Achdiawan R. 2004. Rattan, rubber or oil palm: cultural and financial considerations for farmers in Kalimantan. Economic Botany 58:S77-S87. https://doi.org/10.1663/00 13 -

\section{1(2004)58[77:RROOPC]2.0.CO;2.}

Carlson KM, Curran LM, Ratnasari D, Pittman AM, SoaresFilho BS, Asner GP, Trigg S, Gaveau DA, Lawrence D, Rodrigues HO. 2012. Committed carbon emissions, deforestation, and community land conversion from oil palm plantation expansion in West Kalimantan, Indonesia. Proceedings of the National Academy of Sciences 109(19):7559-7564. https://doi.org/10.1073/pnas. 120045 2109.

Carlson KM, Curran LM, Asner GP, Pittman AM, Trigg SN, Adeney JM. 2013. Carbon emissions from forest conversion by Kalimantan oil palm plantations. Nature Climate Change 3(3):283-287. https://doi.org/10.1038/ nclimate1702.

Casson A. 1999. The Hesitant Boom: Indonesia's Oil Palm Sub-sector in an Era of Economic Crisis and Political Change. Bogor: Centre for International Forestry Research.

Corley RHV. 2009. How much palm oil do we need? Enviromental Science and Policy 12(2):134-139. https://doi.org/10.1016/j.envsci.2008.10.011.

Edwards DP, Larsen TH, Docherty TDS, Ansell FA, Hsu WW, Derhé MA, Hamer KC, Wilcove DS. 2010. Degraded lands worth protecting: the biological importance of Southeast Asia's repeatedly logged forests. Proceedings of the Royal Society London B 27:82-90.

Euler M, Scharze S, Siregar H, Qaim M. 2016. Oil palm expansion among smallholder farmers in Sumatra, Indonesia. Journal of Agricultural Economics 67(3):658-676. https://doi.org/10.1111/14779552.12163 .

[FAO] Food and Agriculture Organization. 2010. Global Forest Resources Assessment 2010: Terms and Definition. Forest Resources Assessment Programme. Working paper 144. Food and Agriculture Organization of the United Nations. Rome, Italy. www.fao.org/docrep/014/am665e/ am665e00.pdf [08 Feb 2017]

[FAO] Food and Agriculture Organization. 2014. The State of Food and Agriculture. Innovation in family farming. Food and Agricultural Organization, Rome. http://www.fao.org/3/a-i4040e.pdf [17 March 2015]

Fauzi N. 2013. Mengapa konflik-konflik agraria terus menerus meletus di sana sini? Jurnal Ilmu Pemerintahan 41:33-49.

Feintrenie L, Chong W, Levang P. 2010. Why do farmers prefer oil palm? Lessons learnt from Bungo District, Indonesia. Small-scale Forestry 9(3):379-396. https://doi.org/10.1007/s11842-010-9122-2.

Fitzherbert EB, Struebig M J, Morel A, Danielsen F, Brulh CA, Donald PA, Phalan B. 2008. How will oil palm expansion affect biodiversity? Trends in Ecology and Evolution $23\left(\begin{array}{ll}1 & 0\end{array}\right): 538-545$. 
https://doi.org/10.1016/j.tree.2008.06.012.

Gunarso P, Hartoyo ME, Agus F, Killeen T. 2013. Oil Palm and land use change in Indonesia, Malaysia and Papua New Guinea. Reports from the Technical Panels of the $2^{\text {nd }}$ Greenhouse Gas Working Group of the Roundtable on Sustainable Palm Oil (RSPO). Pp. 29-64.

Hamer KC, Hill JK, Benedick S, Mustaffa N, Sherratt TN, Maryati M, Chey VK. 2003. Ecology of butterflies in natural and selectively logged forests of northern Borneo: the importance of habitat heterogeneity. Journal of Applied Ecology 40(1):150-162. https://doi.org/10.1046/j.13652664.2003.00783.x

Holmes D. 2002 Where have all the forests gone? Environment and Social Development East Asia and Pacific Region discussion paper. Jakarta: The World Bank.

Jelsma I, Schoneveld GC. 2016. Towards more sustainable and productive independent oil palm smallholders in Indonesia: Insights from the development of a smallholder typology. Working paper 210. Bogor: CIFOR.

Kartodihardjo H, Supriono A. 2000. The impact of sectoral development on natural forest conversion and degradation: The case of timber and tree crop plantations in Indonesia. CIFOR Occasional Paper No. 26(E). Bogor: Centre for International Forest Research. http://www.cifor.cgiar.org/ publications/pdf_files/OccPapers/OP-26e.pdf [11 Jan 2017].

Kartodihardjo H, Nugroho B, Putro HR. 2011. Pembangunan Kesatuan Pengelolaan Hutan (KPH): Konsep, Peraturan Perundangan dan Implementasi. Jakarta: Debut Wahana Sinergi.

Koh LP, Wilcove, DS. 2008. Is oil palm agriculture really destroying tropical biodiversity? Conservation Letters 1(2):60-64. https://doi.org/10.1111/j.1755263X.2008.00011.x.

Koh LP. 2009. Can oil palm plantations be made more hospitable for forest butterflies and birds? Journal of Applied Ecology 45(4):1002-1009. https://doi.org/10.1111/j.1365-2664.2008.01491.x.

Koh LP, Miettinen J, Liew SC, Ghazoul J. 2011. Remotely sensed evidence of tropical peatland conversion to oil palm. Proceedings of the National Academy of Sciences 108:5127-5132. https://doi.org/10.1073/pnas.101877 6108 .

Margono A, Potapov P, Turubanova S, Stolle F, Hansen M. 2014. Primary forest cover loss in Indonesia over 2000-2012. Nature Climate Change 4:730-735. https://doi.org/10.1038/nclimate2277.

Miettinen J, Hooijer A, Tollenaar D, Page S, Malins C, Vernimmen R, Shi CH, Liew SC. 2012. Historical Analysis and Projection of Oil Palm Plantation expansion on Peatland in Southeast Asia. ICCT White paper No. 17.
CRISP, Deltares, ICCT. The International Council on Clean Transportation, Washington, DC.

[MoA] Ministry of Agriculture. 2015. Tree Crop Estate Statistics of Indonesia on Palm Oil 2014-2016. Jakarta: Directorate General of Estate Crops.

[MoEF] The Ministry of Environment \& Forests. 2015. National Forest Reference Emission Level for Deforestation and Forest Degradation: In the Context of the Activities Referred to in Decision 1/CP.16 para 70 (REDD+) under the UNFCCC; A Reference for Decision Makers. DG-PPI MoEF Indonesia.

Muin A. 2013. Pengusahaan perkebunan kelapa sawit berwawasan konservasi [dissertation]. Bogor: Bogor Agricultur University

Nugraha A. 2013. Mengakhiri rezim konflik kehutanan: Momentum pasca keputusan MK. In: Darurat Hutan Indonesia. Mewujudkan arsitektur kehutanan Indonesia. Banten: Wana Aksara.

Obidzinski K, Andriani R, Komarudin H, and Andrianto A. 2012. Environmental and social impacts of oil palm plantations and their implications for biofuel production in Indonesia. Ecology and Society 17(1): 25. https://doi.org/10.5751/ES-04775-170125.

Pagiola S. 2000. Land use change in Indonesia. Research Gate https://www.researchgate.net/publication/ 23748814_Land_Use_Change_in_Indonesia [ 11 July 2017]

Peh KSH, de Jong J, Sodhi NS, Lim SLH, Yap CAM. 2005. Lowland rainforest avifauna and human disturbance: persistence of primary forest birds in selectively logged forests and mixed-rural habitats of southern Peninsular Malaysia. Biological Conservation 123(4):489-505. https://doi.org/10.1016/j.biocon.2005.01.010.

Peh KSH, Sodhi NS, De Jong J, Sekercioglu CH, Yap CAM, Lim SLH. 2006. Conservation value of degraded habitats for forest birds in southern Peninsular Malaysia. Diversity and Distributions 12(5):572-581. https://doi.org/10.1111/ j.1366-9516.2006.00257.x.

Primack RB. 2012. Biologi Konservasi. Indrawan M, translator. Translated from: A Primer of Conservation Biology. Jakarta: Yayasan Pustaka Obor Indonesia.

Ramdani F, Hino M. 2013. Land use changes and GHG emissions from tropical forest conversion by oil palm plantations in Riau Province, Indonesia. PLoS ONE 8(7):e70323. https://doi.org/10.1371/journal.pone.0070 323 .

Saptomo A. 2004. Di balik sertifikasi hak atas tanah dalam prespektif pluralisme hukum. Jurisprudence 1(2):207-218.

Sinabutar P. 2015. Penataan tenurial dan peran para pihak 
dalam mewujudkan legalitas dan legitimasi kawasan hutan negara [dissertation]. Bogor: Bogor Agricultural University.

Sunderlin WD, Resosudarmo IAP. 1997. Laju dan penyebab deforestasi di Indonesia: Penelaahan kerancuan dan penyelesaiannya. Occasional Paper No. 9 Dec 1996. Bogor: Center for International Forestry Research. http://ww.cifor.org/publications/pdf files/OccPapers/OP09I.pdf[2Feb 2017].

Sunderlin WD and Resosudarmo IAP. 1996. Rates and causes of deforestation in Indonesia: Towards a resolution of the ambiguities. Occasional Paper No. 9(E). Bogor: Center for International Forestry Research. 9 December 1996.

Tarigan SD, Sunarti, Widyaliza S. 2015. Expansion of oil palm plantation and forest cover changes in Bungo and Merangin Districts, Jambi Province, Indonesia. Procedia Environmental Sciences 24:199-205. https://doi.org/10.1016/j.proenv.2015.03.026.

Uryu Y, Mott C, Foead N, Yulianto K, Budiman A, Setiabudi,
Takakai F, Nursamsu, Sunarto, Purastuti E, Fadhli N, Hutajulu CMB, Jaenicke J, Hatano R, Siegert F, Stuewe M. 2008. Deforestation, Forest Degradation, Biodiversity Loss and $\mathrm{CO}_{2}$ Emissions in Riau, Sumatra, Indonesia: One Indonesian Province's Forest and Peat Soil Carbon Loss over a Quarter Century and its Plans for the Future. Jakarta: WWF. http://assets.panda.org/downloads/ riau_co2_report_wwf_id_27feb08_en_lr_.pdf [March 201] $]$.

Wilcove DS, Koh LP. 2010. Addressing the threats to biodiversity from oil-palm agriculture. Biodiversity and Conservation 19(4):999-1007. https://doi.org/10.1007/ s10531-009-9760-x.

Wicke B, Sikkema R, Dornburg V, Faaij A. 2011. Exploring land use changes and the role of palm oil production in Indonesia and Malaysia. Land Use Policy 28(1):193-206. https://doi.org/10.1016/j.landusepol.2010.06.001. 